\title{
TESTING OF DETECTION CHARACTERISTICS OF THE PASSIVE INFRARED MOTION DETECTORS
}

\author{
Andrej VELAS ${ }^{1}$
}

Research article

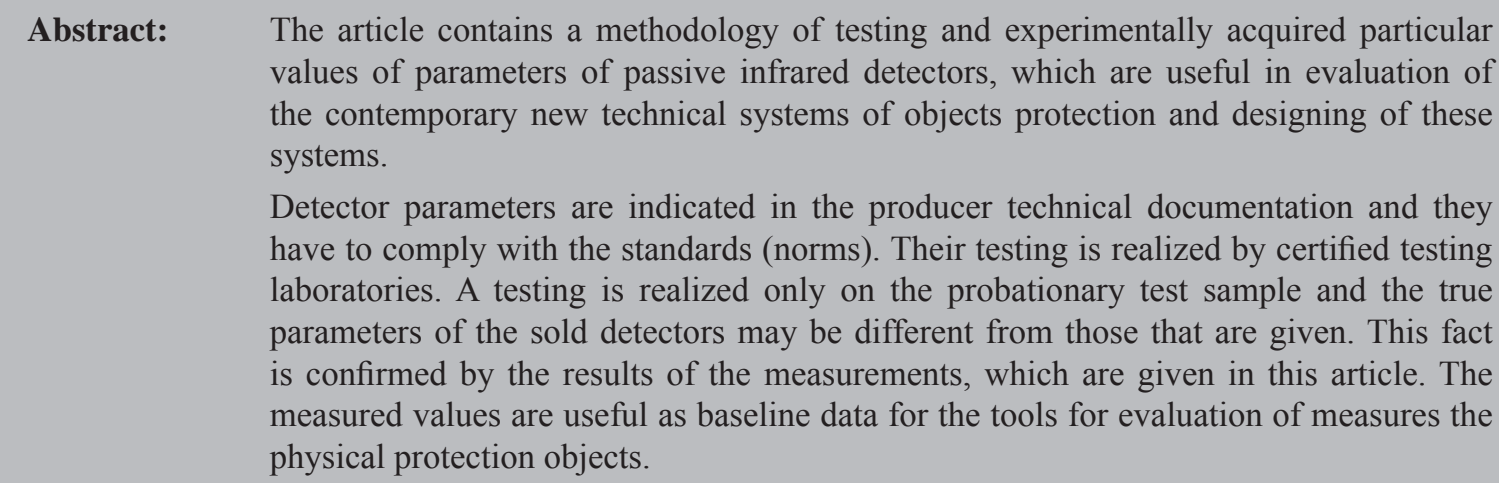

Keywords: Detection, Evaluation, Efficiency, Passive infrared detector, Security.

\section{Introduction}

The main requirements for the intruder alarms systems, whose components are motion detectors as well and thus passive infrared detectors (PIR), are given by the norm EN 50131 Alarm systems. Intrusion and hold-up systems. Conditions of this norm have to be fulfilling by intrusion and hold-up system components.

This norm is a part of package of EN 50130 norms. This norm package indicates the requirements, which are general applicable for alarm systems (for example Environmental test methods EN 50130-5, or the Electromagnetic compatibility in the case of norm EN 50130-4).

The test conditions of components of Intrusion and hold-up systems are stated in individual parts of the norm EN 50131 and the requirements for passive infrared detectors are given in section 2-2.

Components of Intrusion and hold-up systems have deficiencies, which can be reviewed and measured by only qualified person. This measurements can be realized in an environment, where they will be installed and used (from that one can't deduce conclusions for all components), or in the laboratory conditions.

Compulsory tests after generalization for the passive infrared detectors according the norm EN 50131-2-2 are shown in Tab. 1. This table includes the general requirements for speed and posture during testing of motion detectors.
Tab. 1 General requirements for speed and posture of body (EN 50131-2-2, 2012)

\begin{tabular}{|c|c|c|c|c|}
\hline Test & Grade 1 & Grade 2 & Grade 3 & Grade 4 \\
\hline $\begin{array}{l}\text { Detection at the } \\
\text { boundary }\end{array}$ & Required & Required & Required & Required \\
\hline Velocity $\left[\mathrm{m} \cdot \mathrm{s}^{-1}\right]$ & 1.0 & 1.0 & 1.0 & 1.0 \\
\hline Posture & Upright & Upright & Upright & Upright \\
\hline $\begin{array}{l}\text { Detection within } \\
\text { the boundary }\end{array}$ & Required & Required & Required & Required \\
\hline Velocity $\left[\mathrm{m} . \mathrm{s}^{-1}\right]$ & 0.3 & 0.3 & 0.2 & 0.1 \\
\hline Posture & Upright & Upright & Upright & Upright \\
\hline $\begin{array}{l}\text { Detection at high } \\
\text { velocity }\end{array}$ & $\begin{array}{c}\text { Not } \\
\text { required }\end{array}$ & Required & Required & Required \\
\hline Velocity $\left[\mathrm{m} \cdot \mathrm{s}^{-1}\right]$ & - & 2.0 & 2.5 & 3.0 \\
\hline Posture & - & Upright & Upright & Upright \\
\hline $\begin{array}{l}\text { Close-in detection } \\
\text { performance }\end{array}$ & Required & Required & Required & Required \\
\hline Distance $[\mathrm{m}]$ & 2.0 & 2.0 & 0.5 & 0.5 \\
\hline Velocity $\left[\mathrm{m} \cdot \mathrm{s}^{-1}\right]$ & 0.5 & 0.4 & 0.3 & 0.2 \\
\hline Posture & Upright & Upright & Crawling & Crawling \\
\hline $\begin{array}{l}\text { Intermittent } \\
\text { movement } \\
\text { detection } \\
\text { performance }\end{array}$ & $\begin{array}{l}\text { Not } \\
\text { required }\end{array}$ & $\begin{array}{l}\text { Not } \\
\text { required }\end{array}$ & Required & Required \\
\hline Velocity $\left[\mathrm{m} \cdot \mathrm{s}^{-1}\right]$ & - & - & Required & Required \\
\hline Posture & - & - & Upright & Upright \\
\hline $\begin{array}{l}\text { Significant } \\
\text { reduction of } \\
\text { detection range }\end{array}$ & $\begin{array}{l}\text { Not } \\
\text { required }\end{array}$ & $\begin{array}{l}\text { Not } \\
\text { required }\end{array}$ & $\begin{array}{l}\text { Not } \\
\text { required }\end{array}$ & Required \\
\hline Velocity $\left[\mathrm{m} \cdot \mathrm{s}^{-1}\right]$ & - & - & - & 1.0 \\
\hline Posture & - & - & - & Upright \\
\hline
\end{tabular}

University of Žilina, Faculty of Special Engineering, Department of Security management, Žilina, Slovak Republic, andrej.velas@fsi.uniza.sk 
The purpose of the detector tests is first of all to verify the correct operation of the detectors according to the specifications given by the producer. All test parameters introduced have to be fulfilled within the tolerance range of $\pm 10 \%$, unless otherwise instructed. When carrying out the tests it is necessary to comply with the assembly and operation instructions stated by the producer.

\section{Materials and methods}

Testing the detection characteristic of different types of passive infrared detectors and from different producers was realized at the Department of Security Management FSI ZU in Zilina in the last three years and the tests continue in the present as well. The workplace has equipment and competence to perform these tests according to set of norms EN 50130 .

A standard laboratory conditions (prescribed by norm) for the testing of alarm systems must have a standard atmospheric conditions, which are prescribed by EN 50130-5 norm:

- temperature $\left(15-35^{\circ} \mathrm{C}\right)$,

- relative humidity (25\% $\mathrm{RH}-75 \% \mathrm{RH})$,

- air pressure (86 - $106 \mathrm{kPa})$.

The environment should be indoor and there shouldn't be any air flow. The size of the space wherein the detectors are tested should by at least $25 \%$ larger than the coverage of the space, which is guaranteed by the producer of the detector (EN 50130-5, 2012).

The standard walk test target (SWT) must be a person with a height of 160 to $185 \mathrm{~cm}$ and weight $70 \mathrm{~kg} \pm 10 \mathrm{~kg}$. In the norm are given also requirement about clothes of a person.

The physical parameters of the environment in which are detectors measured: standard indoor environment, temperature $17-21{ }^{\circ} \mathrm{C}$, humidity $35-60 \%$, light standard conditions 190-220 Lux. Test conditions satisfy the technical standard EN 50131-2-2 Intrusion detectors. Passive infrared detectors.

The detector has to be installed of $2.0 \mathrm{~m}$, if the producers do not indicate different height. The detector must be oriented with a free field of vision for the performed test according specification of producer.

The detector shall be connected to the nominal supply voltage and to the monitoring system, what indicate alarm signals or messages of intrusion. The detector should have 180 seconds to stabilize. If multiple sensitivity modes such as pulse counting are available, any non-compliant modes shall be identified by the manufacturer. All compliant modes must be tested (EN 50131-2-2, 2008; Křeček, 2006).

Technical equipment:

- PIR detectors (standard Fresnel lens) by different producers - 11 randomly selected pieces from detectors which are available in the market, corresponding to the second grade according to EN 50131,

- wiring material (cables, LED diodes, resistors, clamps),

- assembly and fixative material (tighten and insulation tapes),

- stabilized power supply HY1503D,

- multimeter UT70,

- stopwatch, measuring tape, protractors,

- other accessories.

The description of the technology of the tested detectors: Passive infrared detectors (PIR - Passive infrared receiver) evaluate the changes of radiation in the infrared range of the spectrum of electromagnetic waves. The detection element pyroelectric sensor - is able to detect the changes of the radiation impacting to the detector. The PIR detector evaluates the changes only if the body in his visual field is moving. This body must have a different temperature from ambient temperature. Then the connected electronics will make report about changes. These detectors in the terms of the construction are relatively easy and thanks to that also popular.

The optical system in the detectors uses the set of lenses or set of the parabolic mirrors. The lenses are placed in the detectors in order to be pyroelectric sensor directly in the focus of the lenses. From the lens, which are made mainly from plastic material are mainly used the stepped so-called Fresnel lenses.

Connection: The connection of the detectors control panel and its programming is time consuming. Because of that the detectors were according the tests connected by using signal LED, directly to the stabilized power supply. With this method was a delay, caused by evaluation by circuit of the exchange, eliminated. Detectors were powered by a stabilized one-way voltage. The change of the state was visual count down from LED diodes connected and switched by the contacts of the NC (Normally Closed) detector. 
The drawing of possible involvement of detector during testing:

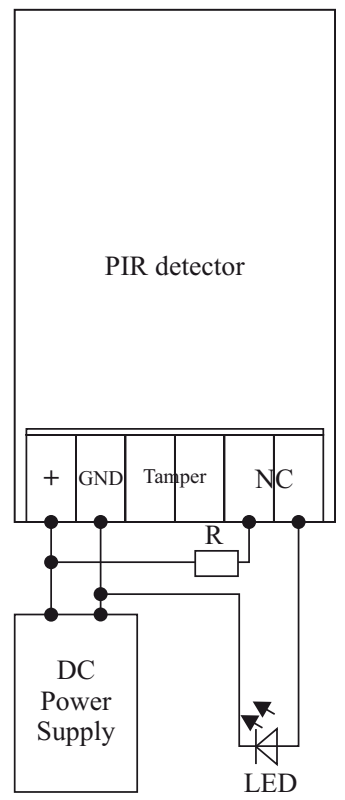

Fig. 1 Connection of PIR detectors during tests (where: NC - Normally Closed, GND - ground)

Process: Each detector was stabilized in the test environment before the test started. Before the performing of the individual tests according the norm, was necessary to perform basic detection test to verify the correct functioning of the detector. The basic detection test was performed in this way: SWT moved in a distance of $2 \mathrm{~m}$ upright to the axis of the detector at a speed from $0.5 \mathrm{~m} . \mathrm{s}^{-1}$ to $1 \mathrm{~m} . \mathrm{s}^{-1}$. After each transfer of the detector, change of its settings or after a manipulation from which was detector damage, had to be perform the basic detection test. When the test was succeeding, we could continue with the next test.

Subsequently was performed the testing of the detection characteristics of the selected passive infrared motion detectors, based on the technical documentation which is delivered with the detector. On the floor of the supervised premises was marked the detection characteristics - angle, distance and testing points. With the standard detection goal was tested the PIR detector according to EN 50131-2-2 norm. There was realized the tests of the Detection at the boundary, Detection within the boundary, Detection at high velocity, Close-in detection performance, Intermittent movement detection performance, Significant reduction of specified range. For each tests for each experiment was performed the graphic protocols, which consist from the redrawing of detection characteristics of the single detector and from the plotting of the reviewed detection points. Following is shown the description of each tests according to EN 50131-2-2 Chapter 6 - Walk testing.

\section{Results}

There were tested 11 different analog and digital passive infrared motion detectors from different producers during the practical measurements. From each producer were used 3 of their products. All of 11 motion detectors corresponded to the use of objects with low or moderate level of risk - Grade 2 according to EN 50131. There were 5 repetitions of measuring for each detector. Together, 165 measurements have been done, while each measurement consisted 5 subtests. Overall have been performed 825 tests.

\section{Testing the coverage of detection at the boundary}

During verifying the detection at the boundary it is necessary to illustrate the test positions of the measurement. Test positions were spaced every two meters along the whole perimeter of the test area boundaries and they had to be spaced from the both sides of the detector.

Each test position was placed on the radial junction with detector and at each test position were shown two test directions with $+45^{\circ}$ to the radial junction and $-45^{\circ}$ to the radial junction. Each test point was accessed from a distance of 1.5 meters from it; by walking was tested pass through the test point to a distance $1.5 \mathrm{~m}$ over it.

The direction of movement was heading to the inside of detection area. After each individual movement the SWT stayed 20 seconds still. For all of detectors was applied upright movement and movement velocity of $1 \mathrm{~m} . \mathrm{s}^{-1}$. The speed of movement was complied by an estimated using metronome and with transfer distance test with value 10 meters for time 10 seconds and then could continue the testing with using similar speed (Mrázik, 2010).

Transfer distance test might be confirming in all of testing positions and both testing directions. After this fact, it can be said that the detector complied test of detection at the boundary, otherwise it failed. As shown in the figure below, not all detectors complied this test and according to the measured results in the majority of tested PIR detector is a noticeable reduction of detection at the boundary covering space. 


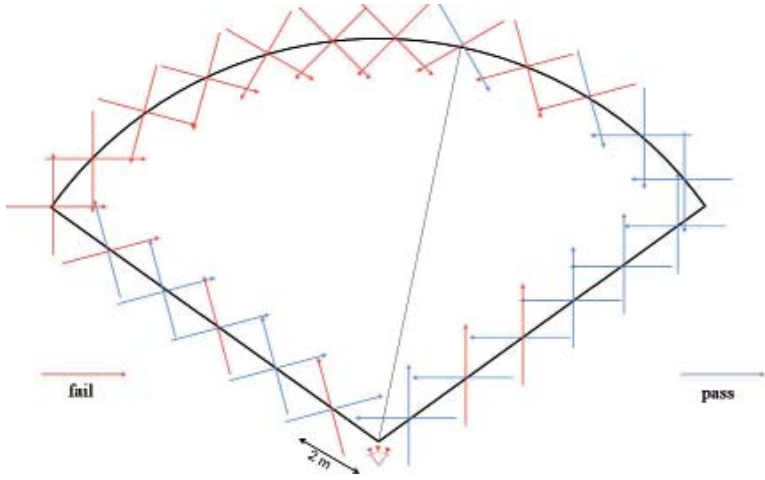

Fig. 2 Detection test result of one of the detection across the boundary (Mrázik, 2010)

\section{Testing coverage detection within the boundary (inside boundary)}

This test is intended to verify detection within the boundary. The measurements were carried out to test positions within the detection characteristics that have to be marked. The first test position was placed $4 \mathrm{~m}$ from the detector directly on its axis and marked on the floor. Additional test positions were stationed at the intersection of a square grid of size $2 \mathrm{~m}$ on either side of the axis of the detector. Square grid was outlined with string and test points were shown on the floor. No test point should be located closer than $1 \mathrm{~m}$ from the boundary or outside the boundary (Mrázik, 2010).

As in the previous measurement, such in this case the detector has been tested with the movement through test position in two directions to $+45^{\circ}$ and $-45^{\circ}$ to the radial line. The movement began $1.5 \mathrm{~m}$ before test point and ended 1.5 meters behind it. After each individual movement the SWT stayed 20 seconds still. The speed of movement was dependent on the security level of the detector and it is defined in Tab. 1.

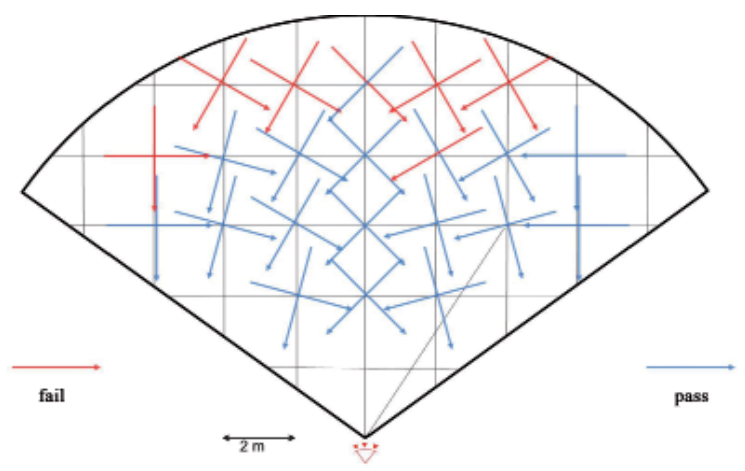

Fig. 3 The result of the detection test of one of the detectors within the boundary (Mrázik, 2010)
Transfer test must be suitable for all test positions in both test directions and then we say that detector complied the detection test within the boundary, otherwise it failed (Palica, 2011). 5 motion detectors failed the test, while the coverage of detection at the boundary, where may be considered a distortion of at least $10 \%$, it is impossible to cover the inside of the detection area with different detector due to a significant reduction in detection.

\section{Testing detection at high velocity}

High velocity to perform this test means a velocity of $2.0 \mathrm{~m} . \mathrm{s}^{-1}$ and the velocity $3.0 \mathrm{~m} . \mathrm{s}^{-1}$. The size of speed depends on the security level of tested detector (Tab. 1). For measurements for the verification of high-speed detection is required to move at velocity of $2.0 \mathrm{~m} . \mathrm{s}^{-1}$ to $2.5 \mathrm{~m} . \mathrm{s}^{-1}$. Applies to all levels of upright posture. There were done totally 4 tests for each of tested detectors to verify the detection at high velocity (Mrázik, 2010).

The accomplishment of detector in detection test at high velocity is done when alarm signal is generated in all four tests.

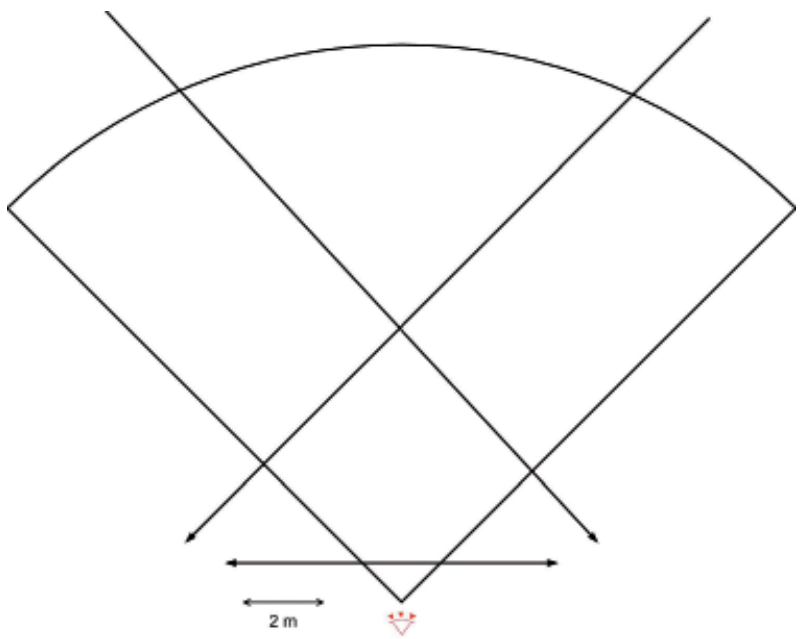

Fig. 4 High velocity and intermittent movement (Mrázik, 2010)

By changing the angle of movement indicated speed of $45^{\circ}$ to movement vertical to the axis of the detector is probability of overcoming the PIR detector relatively high, reaching values of about $80 \%$ of attempts.

\section{Testing intermittent movement detection performance}

For verification of intermittent movement detection were performed two tests, whose were the same as for verification of detection at high speed. To 
the centre of the detector's axis was indicated a point and detector has been tested at this point, moving at an angle of $+45^{\circ}$ and $-45^{\circ}$ over all detection zones. Movement detection started always away from the detector boundaries towards a detector of velocity $1 \mathrm{~m} . \mathrm{s}^{-1}$.

To comply verification of intermittent movement detection, the alarm signal has to be generated in all four tests.

All tested detectors passed the verification, but for detectors with pulse counting circuit can be accessed near the centre of the detection area without activating an alarm.

\section{Close-in detection performance}

Tab. 1 defines the speed of movement and posture of the body, which is required for this test. It is also depending on the degree of security. For Close-in detection performance at a distance $0.5 \mathrm{~m}$ were made two tests passing (bi- directional) desired speed across testing point for each detector.
Tab. 2 Test results of detecting an intruder through transition of the PIR detector characteristic

\begin{tabular}{|l|c|}
\hline \multicolumn{1}{|c|}{ Test } & $\begin{array}{c}\text { Unsatisfactory result } \\
\text { (number of detectors - } \\
\text { out of 11) }\end{array}$ \\
\hline Detection at the boundary & 8 \\
\hline $\begin{array}{l}\text { Detection within the } \\
\text { boundary }\end{array}$ & 5 \\
\hline Detection at high velocity & 0 \\
\hline $\begin{array}{l}\text { Close-in detection } \\
\text { performance }\end{array}$ & 4 \\
\hline $\begin{array}{l}\text { Intermittent movement } \\
\text { detection performance }\end{array}$ & 0 \\
\hline
\end{tabular}

Although those detectors are used in practise, during the designing of security systems is necessary to count with some deviation of detection characteristics. Also is useful to cover area with more as one motion detectors with overlaps of detection characteristic.

Tab. 3 Test results of detecting an intruder through transition of the PIR detector characteristic

\begin{tabular}{|c|c|c|c|c|c|c|c|c|c|c|c|}
\hline & \multicolumn{4}{|c|}{ Producer A } & \multicolumn{3}{|c|}{ Producer B } & \multicolumn{4}{|c|}{ Producer C } \\
\hline & $\begin{array}{c}\text { Detector } \\
1\end{array}$ & $\begin{array}{l}\text { Detector } \\
\quad 2\end{array}$ & $\begin{array}{l}\text { Detector } \\
3\end{array}$ & $\begin{array}{c}\text { Detector } \\
4\end{array}$ & $\begin{array}{l}\text { Detector } \\
5\end{array}$ & $\begin{array}{l}\text { Detector } \\
\quad 6\end{array}$ & $\begin{array}{l}\text { Detector } \\
7\end{array}$ & $\begin{array}{c}\text { Detector } \\
8\end{array}$ & $\begin{array}{c}\text { Detector } \\
9\end{array}$ & $\begin{array}{l}\text { Detector } \\
10\end{array}$ & $\begin{array}{c}\text { Detector } \\
11\end{array}$ \\
\hline $\begin{array}{l}\text { Detection at the } \\
\text { boundary }\end{array}$ & 0.88 & 0.85 & 0.78 & 0.83 & 0.97 & 0.95 & 1.00 & 0.74 & 0.77 & 0.89 & 0.29 \\
\hline $\begin{array}{l}\text { Detection within the } \\
\text { boundary }\end{array}$ & 0.98 & 0.97 & 0.88 & 0.94 & 0.96 & 0.96 & 1.00 & 0.62 & 0.68 & 0.91 & 0.59 \\
\hline $\begin{array}{l}\text { Detection at high } \\
\text { velocity }\end{array}$ & 1.00 & 1.00 & 1.00 & 1.00 & 1.00 & 1.00 & 1.00 & 1.00 & 1.00 & 1.00 & 1.00 \\
\hline $\begin{array}{l}\text { Close-in detection } \\
\text { performance }\end{array}$ & 0.93 & 0.73 & 0.27 & 1.00 & 1.00 & 1.00 & 1.00 & 0.67 & 0.00 & 0.00 & 1.00 \\
\hline $\begin{array}{l}\text { Intermittent movement } \\
\text { detection performance }\end{array}$ & 1.00 & 1.00 & 1.00 & 1.00 & 1.00 & 1.00 & 1.00 & 1.00 & 1.00 & 1.00 & 1.00 \\
\hline
\end{tabular}

In order to confirm, that detector succeed during the test close-in detection performance, has to generate alarm signal during test in both directions. The test highly depends on right location of detector. The overcome of detector by this way is simply and allows to violator access close-in to the detector (Vel'as, 2011).

Tab. 2 defines about the general results of PIR detection of detectors in individual tests. Tab. 3 contains complex values of detection probabilities of violator according to detector. In consideration of number of measurements we can eliminate mistakes caused by inaccuracy of the measurements.

From the 11 types of PIR motion detectors, which were tested with standard motion Fresnel lens, 9 types of motion detectors (by different producers) didn't satisfy repeatedly at least in one part of the test. Those mistakes were verified by 3 pieces from concrete types of detector.
How the standard EN 50131-2-2 specified the possible tolerance in individual tests has to be $\pm 10 \%$. If the detector didn't pass in at least one of the test by passing, it means that didn't correspond to the standard (Palica, 2011).

The possible existence of uncovered zones in supervised premises can destroy the security of whole system. Just one unsatisfactory element means that whole system (which can be functional) didn't fulfil requirements of standard for security of property. These requirements are referred by this standard (e.g. policy conditions of insurance companies. 


\section{Conclusion}

Although the components declare some specific level of security, during the application in real object a plumber doesn't know consider whether the conditions, which were written in the technical standard, were achieved that specific level. In practice the plumber is not able to verify technical specifications which are declared by the producer. For that reason he is following the technical documentation and certificates which were added with installed component. He also has to use his practical skills.

The quality control of components should be made by state test organisation (in testing laboratories), that are aimed to electrical safety of checked components and doesn't check the ability of reliability or detection of the components. The tests of reliability and detection abilities are not made to all components of alarm systems. It's not possible to check all components for many reasons (financial, personnel, time etc.). For that reasons just some selected elements (samples) from each production set are tested. Based on the obtained results, testing itself should be necessary made continuously even in case of the products which are recently sold (accidentally or sporadically).

Based on the measurements which were made at Faculty of Special Engineering of University of Zilina were shown that there are the lack of alarm systems in detection ability of the detectors:

- the motion detectors don't fulfils parameters and detection characteristics which are written in technical documentation, which is added by producer,

- detectors fulfils just the minimum of requirements which were specified in the technical standards. Each change of environment parameters, the size of detection target or the direction, the method and the speed of movement can create the conditions for violation of the supervised premises,

- the detectors are not resistant toward overcome by common available means.

A possible reason for not fulfil the parameters which were specified in the technical documentation is, that for testing are selected just selected types of concrete products. From production are sold also products which don't fulfil parameters according to legislations.

In consideration of the results of measurements, it's necessary to take into account characteristic of detector. In the course of projecting security system consider with variance since declared parameters of detection at the boundary of detection space
$-20 \%$. The increase of detection capability is currently possible overlap of detectors detection characteristics.

Based on practical tests can be stated, that during checking the detectors is necessary to spread testing methods about motion detection with speed faster than $3 \mathrm{~m} \cdot \mathrm{s}^{-1}$. The direction has to be upright to the axis of the detector and not with angle $45^{\circ}$ as was written in standard. Most of the PIR detectors from second and third class could overcome by canter and faster speed in upright direction to the axis of detector without intermittent movement. This situation can happen in objects, where the detectors are situated in areas of long corridors or in rooms without any barriers, which allow reach specified speed.

Standard detection target is specified so narrowly that disregards persons whose weight is less than $70 \mathrm{~kg}$. There is also problem with height of persons. Persons who don't have height between 160 and $185 \mathrm{~cm}$ needn't be detected by motion detector. These assumption about the height and the weight needn't comply young people, women. In this case there could be decrease of the possibility detection. In case that person who disrupted the supervised premises weren't in standard clothes (e.g. have wearing a winter jacket), it can seriously affected the of results detection. The same case can happen when person is coming from colder (outdoor) environment to the protected area.

Nowadays detectors require changes of constructions not just in principles of detection and evaluation of violation. The area of design is also important. Currently is popular miniaturization, but still didn't intervene to alarm systems. The design or the size of intruder alarm systems components didn't change radically in last 20 years. There was also no big change in technologies of detection which are used in common detectors which are available on the market.

\section{Acknowledgments}

The paper was supported by the Slovak Research and Development Agency under the contracts: No. APVV 0471-10. 


\section{References}

BROOKS, D. J. (2011) Intruder Alarm Systems: Is the Security Industry Installing and Maintaining Alarm Systems in Compliance to Australian Standard AS2201? In: Security Journal. Volume: 24, Issue: 2, p. 101-117. ISSN 0955-1662.

KŘEČEK, S. (2006). Př́ručka zabezpečovaci techniky. Blatná: Blatenská tiskárna, 2006. ISBN 80-902938-2-4 (in Czech).

MRÁZIK, P. (2010). Meranie vlastností EZS a ich komparácia s údajmi udávanými výrobcami. Diplomová práca, obhájená 2010, Žilinská univerzita v Žiline, Fakulta špeciálneho inžinierstva, školitel': Ing. Andrej Vel'as, PhD. (in Slovak).

NOVÁK, L., LUSKOVÁ, M. (2012). Možnosti použitia štatistiky pri skúmaní rizík v priemyselnej oblasti. In: Menadžment 2012: međunarodna naučna konferencija: zbornik radova: Mladenovac, Serbija, 20-21. april 2012. - Mladenovac: Fakultet za poslovno industrijski menadžment; ICIM plus, 2012. ISBN 978-86-8490974-1. (in Slovak).

PALICA, I. (2011). Meranie vlastnosti prvkov elektrických zabezpečovacích systémov. Diplomová práca. Fakulta špeciálneho inžinierstva, ŽU v Žiline, 2011. (in Slovak).

PHILlIPS, B. (2001). The Complete Book of Electronic Security. McGraw-Hill Professional, 2001. ISBN $978-$ 0071380188.

ŠČUREK, R., ŠVEC, J., ŠVEC, P. (2011). Využití fyzikálních poznatků v bezpečnostním inženýrství. In: Communications. Žilina: Žilinská univerzita, 2011, s. 114-117. ISSN 1335-4205. (in Czech).

VALOUCH, J. (2012). Integration Techniques Of Alarm Systems. In: TRANSACTIONS of the VŠB - Technical University of Ostrava. Safety Engineering Series. Vol. 2012, No. 1, p.65-72. ISSN 1801-1764.

VELAS, A. (2011). Detektory pracujúce na elektromagnetickom princípe - Skúmanie pasívnych infračervených detektorov. In: Medzinárodní bezpečnostní konference „Bezpečnostní Technologie, Systémy a Management 2011 “. Zlín: Univerzita Tomáše Bati ve Zlíne, 2011. Príspevky prošli recenzí. ISBN 978-80-7454-111-7. (in Slovak).

EU s.r.o., 2012. ISSN 1801-1764.

EN 50131 (2011). Alarm systems. Intrusion and hold-up systems.

EN 50131-2-2 (2008). Intrusion detectors. Passive infrared detectors.

EN 50130-5 (2012). Alarm systems. Environmental test methods.

EN 50130-4 (2012). Alarm systems. Electromagnetic compatibility. Product family standard: Immunity requirements. 